\title{
Patterns of oral contraceptives consumption and estimated concentrations of $17 \alpha$-ethinylestradiol in water bodies from the municipality of Santa Maria Madalena, Southeastern Brazil
}

\author{
Da Cunha, D.L. ${ }^{*}$; Muylaert, S. ${ }^{2}$; Do Nascimento, M.T.L. ${ }^{3}$; Bila, D.M. ${ }^{4}$; SARCinelli, P.N. ${ }^{1}$ \& \\ LARENTIS, A.L. ${ }^{1}$ \\ ${ }^{1}$ National School of Public Health Sérgio Arouca, Oswaldo Cruz Foundation. \\ ${ }^{2}$ State Environment Institute (INEA), Rio de Janeiro. \\ ${ }^{3}$ Institute of Geosciences, Federal Fluminense University. \\ ${ }^{4}$ Department of Sanitary Engineering and Environment, Rio de Janeiro State University.
}

Received August 14, 2019; Accept May 15, 2020

\begin{abstract}
Organic contaminants with estrogenic activity have generated increasing concerns in the scientific community since they are capable of triggering adverse effects in the endocrine system of several organisms. 17 $\alpha$-ethinylestradiol (EE2), a synthetic estrogen used in oral contraceptives, has been identified as one of the main responsible for causing such changes. Thereby the objective of this study was to generate information on EE2 consumption and estimate its possible impact on the water bodies of Santa Maria Madalena. Firstly, a survey was carried out about EE2 consumption through interviews with 325 women aged 15 to 59 residing in the study area, and then estimated the EE2 release in the water bodies. About $30 \%$ of the women interviewed reported using oral contraceptives. The EE2 average daily intake for each woman was $20 \mu \mathrm{g}$ day ${ }^{-1}$. Extrapolating this intake to $30 \%$ of the population and adopting an excretion rate of $57 \%$, it was calculated a total discharge of $4.8 \mathrm{mg} \mathrm{day}^{-1}$ of this estrogen into the local water bodies. It diluted by the small flow of these streams leads to an estimated environmental concentration of $0.3 \mathrm{ng} \mathrm{L}^{-1}$, which according to ecotoxicological studies is already enough to trigger adverse effects to the aquatic biota.
\end{abstract}

Keywords: ecotoxicology; ethinylestradiol; oral contraceptives; water contamination.

\section{INTRODUCTION}

The consumption of pharmaceuticals in the world has gradually increased in last decades. Brazil is noteworthy in this context, since it is among the ten largest consumers in the world, with anti-inflammatories, analgesics, and oral contraceptives being the most consumed pharmaceutical classes (CNS, 2005). This consumption has been generated concern in the scientific community, mainly among ecotoxicologists because once ingested, these pharmaceuticals are excreted in urine and feces as free compounds and/or metabolites, and subsequently may enter the aquatic environment and cause adverse effects on biota. This occurs because certain cell receptors of the animal may resemble those found in humans, increasing the chances of triggering responses (Fent et al., 2006).

In Brazil, about $30 \%$ of women aged 15 to 44 use oral contraception as a contraceptive method (Ministério da Saúde, 2009). The main active principle in these widely marketed pharmaceuticals is the synthetic estrogen $17 \alpha$-ethinylestradiol (EE2), which has high estrogenic activity. In addition to oral contraceptives, other hormonal contraceptives of different pharmaceutical forms (transdermal patch, injectable, vaginal ring, etc.), as well 
as pharmaceuticals used in female hormone replacement therapy (HRT), may also contain EE2 as active principle.

The EE2 estrogen is classified as an endocrine disruptor and can cause adverse effects in several organisms due to its potent estrogenic activity, even in extremely low concentrations (Cunha et al., 2016). According to Sumpter and Johnson (2005) and Runnalls et al. (2010) estrogens, such as EE2, can induce adverse effects on fish reproduction in concentrations below $1 \mathrm{ng} \mathrm{L}^{-1}$. One of the most observed effects is the induction of vitellogenin synthesis in male fish, which can compromise the balance of the affected species. The continuous exposure to EE2, documented in the literature, in laboratory and field studies, has been broadly associated with changes in mating behavior and development, biochemical, morphological and histopathological alterations, spawning delays and decreases in fertilization rates, and others effects (Volkova et al., 2015; Garmshausen et al., 2015; Bhandari et al., 2015; Luna et al., 2015; Giusti et al., 2014; Hoffmann \& Kloas, 2012; Salierno \& Kane, 2009; Jaser et al., 2003). Among these adverse EE2 exposure effects, the most alarming is feminization, which causes part of the exposed male population to become intersex, exhibiting female sexual characteristics including female reproductive anatomy (Gilbert, 2012; Salierno \& Kane, 2009; Zha et al., 2007; Van Aerle et al., 2002; Metcalfe et al., 2001).

Although there are a number of studies that demonstrate the ecotoxicological effects of the estrogens, research quantifying their presence in aquatic matrices, as well as indicating improvements in wastewater treatment technologies and in the regulatory framework, both in Brazil and worldwide, are still incipient. In this context, the present study generates information regarding the consumption of the synthetic estrogen EE2 and estimates its possible impact on water bodies of the municipality of Santa Maria Madalena, Rio de Janeiro, Brazil.

Santa Maria Madalena is located in the state of Rio de Janeiro, Southeastern Brazil, the urban area of its $1^{\text {st }}$ district, was selected for this case study since this area does not present pharmaceutical industries, animal breeding sites or other potential sources of EE2. Therefore, the occurrence of this estrogen in the local water can be directly related to hormonal contraceptives intake. Another important point is that this area also has no potential sources of this compound upstream of the researched area. Therefore, the consumption of pharmaceuticals containing EE2, inside the studied area can indicate the occurrence of this estrogen in its water bodies.

\section{MATERIAL AND METHODS}

\section{Study Area}

Situated in the mountain region of Rio de Janeiro State, the municipality of Santa Maria Madalena has $815 \mathrm{~km}^{2}$ and is distributed throughout six districts (Figure 1). Its population is of 10,321 inhabitants, of which 5,932 are urban area residents (mostly concentrated in the $1^{\text {st }}$ district) and 4,389 are rural area residents (IBGE, 2010).
The water bodies that drain the urban area of the $1^{\text {st }}$ district are the Ribeirão Santíssimo and the São Domingos streams (Figure 1), both the Rio Grande River tributaries.

The sewage treatment system is currently operated by the municipality itself. There are two sewage treatment plants (STPs) in the urban area of the $1^{\text {st }}$ district with a biological treatment system at a secondary level (PMSB, 2012). STP I is installed near the São Domingos stream, receiving only the contribution of the Cidade Alta neighborhood, while STP II is located near the Ribeirão Santíssimo stream and receives inputs from the Largo do Machado and Arranchadouro neighborhoods. The central area, Itaporanga, and Jardim Nova Madalena neighborhoods are not served by any treatment plants. However, even with two STPs, a good part of the sanitary effluents does not receive any treatment before being released water bodies, due to some factors: (1) not the whole area is covered by a sewage network; (2) in some cases, where there is the collection network a part of the households is not connected to it; and (3) there are areas with collection network, but it is not linked to the treatment stations. These releases of in natura sewage to the local water bodies can cause a number of drawbacks, from unpleasant water appearance and smell to the spread of infectious waterborne diseases.

\section{Survey and Estimated Concentrations of EE2 in the Water}

A cross-sectional epidemiological study (survey) was conducted with women aged 15 to 59 living in the urban area of the $1^{\text {st }}$ district of Santa Maria Madalena, from September to December 2014. This age range was established using population-based studies conducted in Brazil as reference, which indicates that the average age of the first sexual intercourse in young people is 15.7 years old and the maximum age of occurrence of natural menopause is 58 years old (Hugo et al., 2011; Pedro et al., 2003).

A simple random sampling model with a sample error of $5 \%$ and a confidence level of $95 \%$ was conducted for a universe of 2,054 women aged 15 to 59, according to the 2010 census (IBGE, 2010). Based on this methodology, the minimum number of women to be interviewed to meet the statistical criteria of this procedure was 325 . A visiting of households was done until meeting the minimum aimed number of women, in a proportional amount by the census zones, in order to reach an equiprobabilistic sample of this universe.

Data was collected through a questionnaire containing open and closed questions on the following general items: identification, socio-environmental characteristics and consumption of pharmaceuticals (Table 1). The validation of this question sheet was conducted by means of a pre-test performed before the survey to verify the data collection instruments and to confirm the feasibility of the investigation.

Participating women were all the residents present in the selected households, except women in the gestational period or in cases of refusal or inability to participate in the survey. These women were interviewed individually in a reserved place, in order to guarantee their privacy. In the first contact 

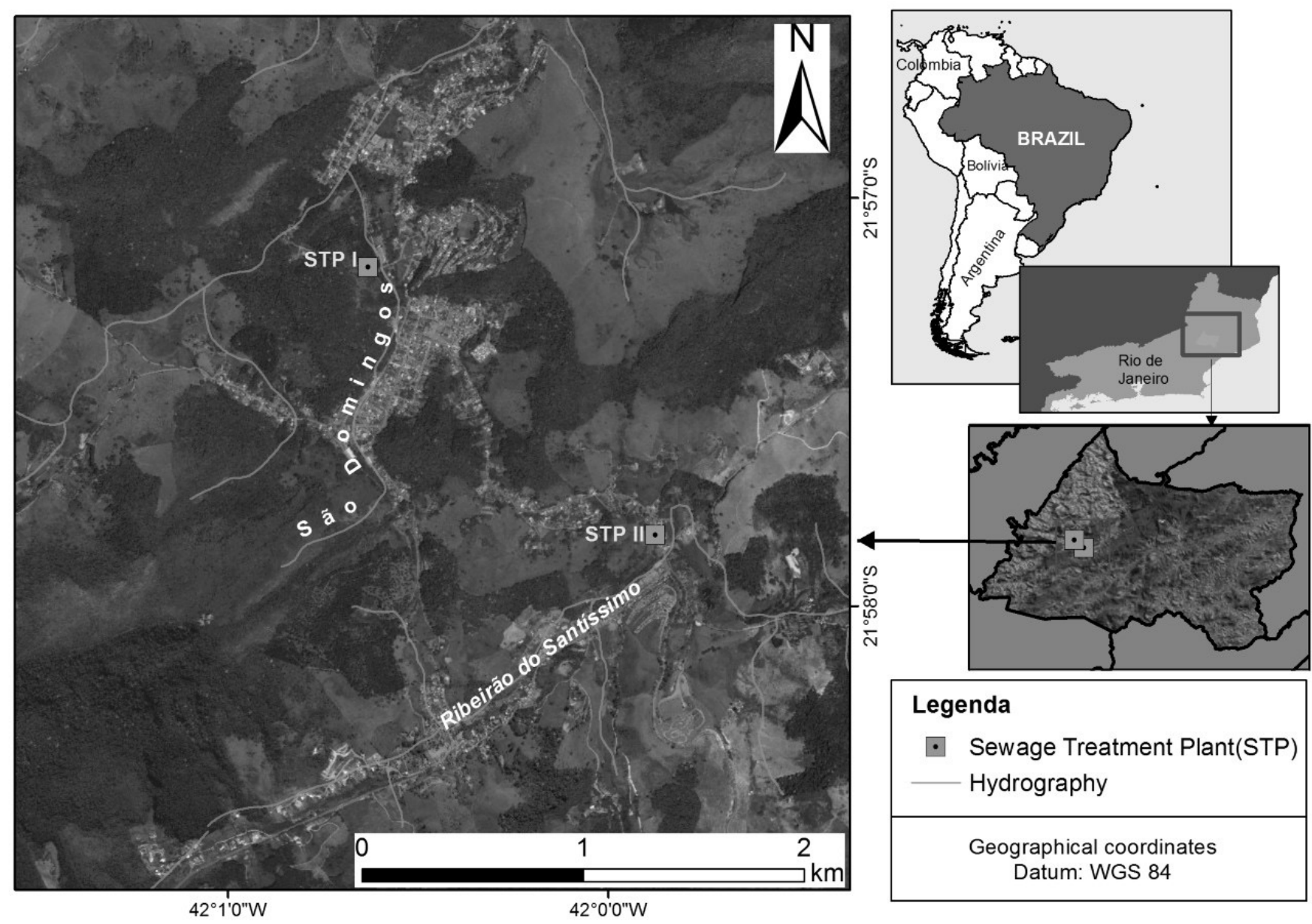

Figure 1: Location and hydrography of the study area.

with each interviewee was explained to them about the objectives of the study and the questions contained in the questionnaire, also emphasizing that personal information would be kept confidential and anonymous. The womenonly participated in the study after signing the Free and Informed Consent Form, in accordance with the principles established in Resolution 196/1996 of the National Health Council (CNS, 1996).

Data organization obeyed ethical criteria, preserving the anonymity of each interviewee. Only the researchers ahead of the survey had access to interviewee identifications. A second free access database, containing the data collected during the interviews, was made using a numerical code identification system.

To complement the study, data was also collected at health centers (Basileu Estrela Hospital, Almeida Santos Colombian Family Health Program, Doutor Manoel Verbicário Central Health Unit) and all local drugstores.

The research protocol was submitted and approved by the Research Ethics Committee of the National School of Public Health/Oswaldo Cruz Foundation (CAAE 17134213.6.0000.5240). The collected data was stored in a database (Epi Info version 6.04) and its analysis was performed using the statistical software SPSS, version 17.0.
In order to evaluate the environmental impact of oral contraceptives into the local water bodies, it was used the methodology proposed by Johnson and Williams (2004). Therefore, based on the rates of metabolism and excretion of the EE2, the release of this estrogen to the water bodies, was calculated through the average administered EE2 dosage (information extracted from the interview data) and then its possible impact on the water environment was estimated, considering the dilution capacity of the streams that drain the region.

\section{RESULTS AND DISCUSSION}

\section{EE2 Consumption Pattern}

The following data presentation considers all interviews ( $\mathrm{n}$ $=325$ ), since no losses or refusals have occurred. The general characteristics of the sampled population according to age, education, occupation, water supply, and sewage treatment are shown in Table 2.

Almost $30 \%$ of the interviewed women reported using oral contraceptives. This result is similar to data of the national pattern of consumption. According to a study conducted by the National Demography and Health Survey 
Table 1: Questionnaire on the consumption pattern of 17 $\alpha$-ethinylestradiol in Santa Maria Madalena - RJ / Brazil.

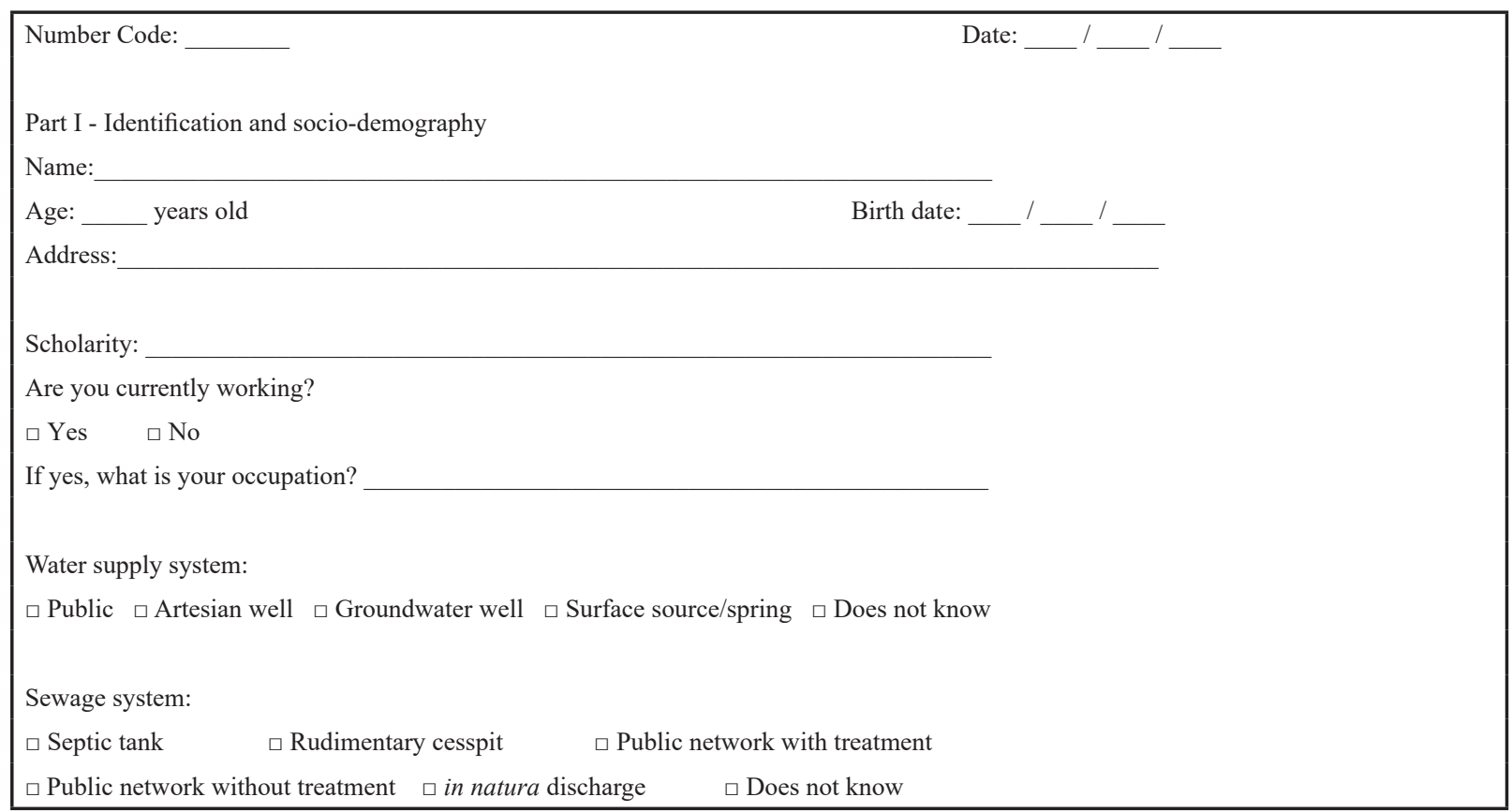

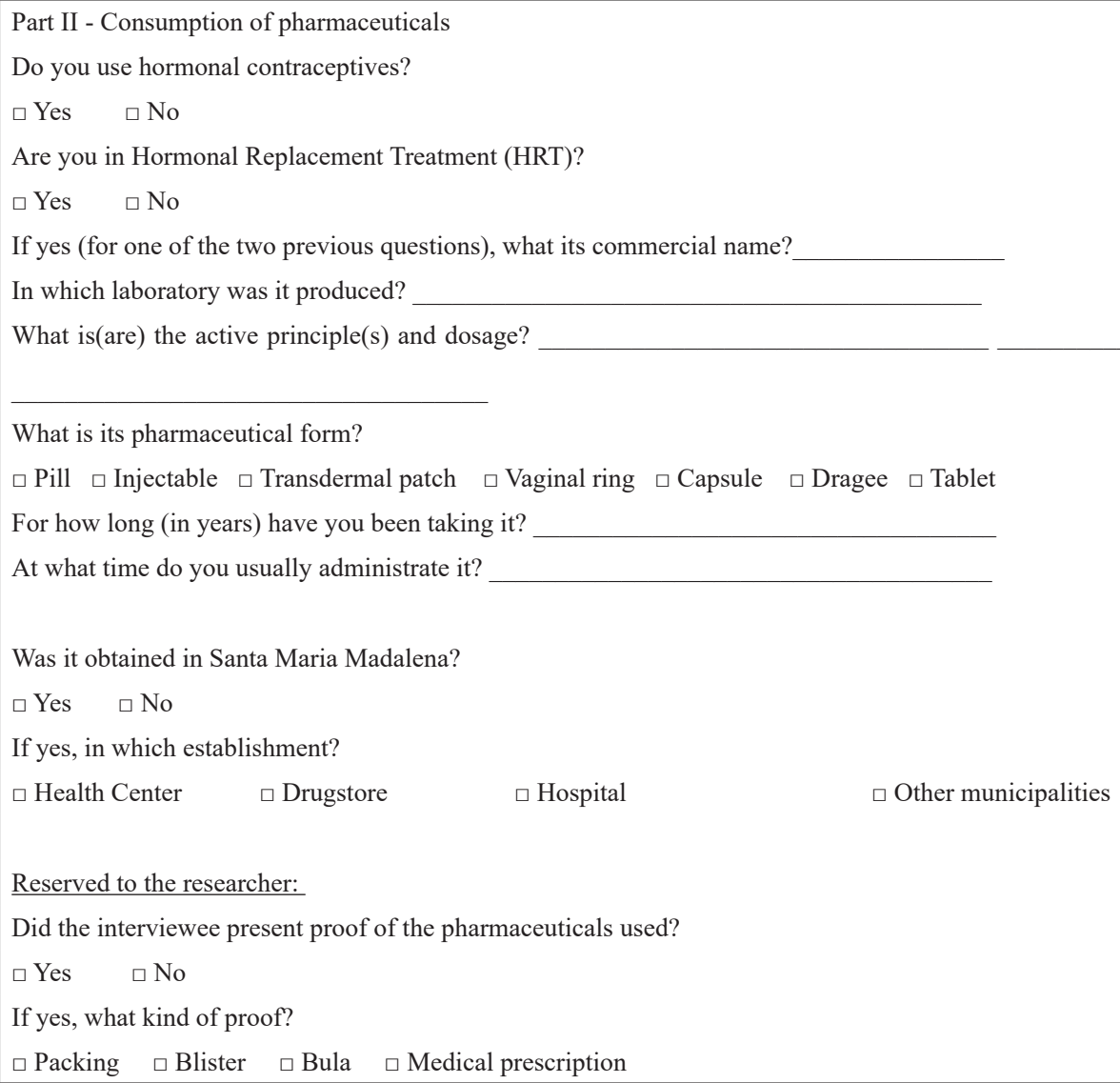

(Pesquisa Nacional de Demografia e Saúde - PNDS), the use of these pharmaceuticals in Brazil in women aged 15-44 was of $23.1 \%$ in 1996, increasing to $27.4 \%$ in 2006 (Ministério da Saúde, 2009).

Information on the consumption of other hormonal contraceptives was also collected, such as transdermal contraceptive patch, vaginal ring and injectable, as well as pharmaceuticals used in the female HRT (Table 2). Only $5.2 \%$ of the interviewees were doing female HRT, and these pharmaceuticals were composed of natural estrogens (17 $\beta$-estradiol, estrone, and estriol) or phytoestrogens. For the other hormonal contraceptives mentioned above, a small 
Table 2: General characterization of the study population $(n=325)$.

\begin{tabular}{|c|c|c|}
\hline \multirow[t]{2}{*}{ Variables } & \multicolumn{2}{|c|}{ Sample } \\
\hline & $\mathbf{N}$ & $\%$ \\
\hline Use of oral contraceptives & 95 & 29.2 \\
\hline Use of others hormonal contraceptive* & 6 & 1.9 \\
\hline Female HTR & 17 & 5.2 \\
\hline Does not use any of these methods & 207 & 63.7 \\
\hline \multicolumn{3}{|l|}{ Age group (years) } \\
\hline 15 to 29 & 109 & 33.5 \\
\hline 30 to 44 & 136 & 41.8 \\
\hline 45 to 59 & 80 & 24.6 \\
\hline \multicolumn{3}{|l|}{ Scholarity (study years) } \\
\hline$\geq 12$ & 87 & 26.8 \\
\hline 9 to 11 & 164 & 50.5 \\
\hline$\leq 8$ & 74 & 22.8 \\
\hline \multicolumn{3}{|l|}{ Employed } \\
\hline Yes & 262 & 80.6 \\
\hline No & 63 & 19.4 \\
\hline \multicolumn{3}{|l|}{ Water supply system } \\
\hline Public & 252 & 77.5 \\
\hline Artesian well & 19 & 5.8 \\
\hline Groundwater well & 10 & 3.1 \\
\hline Surface source/spring & 44 & 13.6 \\
\hline Does not know & - & - \\
\hline \multicolumn{3}{|l|}{ Sewage treatment system } \\
\hline Septic tank & 14 & 4.3 \\
\hline Rudimentary cesspit & - & - \\
\hline Public collection network with treatment & 117 & 36 \\
\hline Public collection network without treatment & 2 & 0.6 \\
\hline in natura release & 185 & 56.9 \\
\hline Does not know & 7 & 2.2 \\
\hline
\end{tabular}

percentage (1.9\%) of the women used injectable contraceptives. And these also had no EE2 as the active principle, only progesterone. Therefore, this discussion primarily just focuses on those numbers related to oral contraceptives, which present the EE2 in their formulations.

The overall mean age of the women interviewed was 35.5 years ( $\mathrm{SD} \pm 11.7)$, with a slightly higher frequency of women between the ages of 30 and $34(14.8 \%)$. It is noteworthy that about $70 \%$ of women reported having at least completed high school education and that the proportion of working women was about $80 \%$.

Regarding sanitation characteristics, $77.5 \%$ of the interviewees stated that the water supply of their households comes from the public network. According to data from the 2010 census (IBGE, 2010), about $80 \%$ of the households in the urban area of the municipality of Santa Maria Madalena are served by public supplier, which corroborates the results found during the survey conducted by the present study. Regarding sewage treatment, $56.9 \%$ of the interviewees stated that their sewage is released directly into the local water bodies (in natura). When comparing this data with those from the 2010 census (IBGE, 2010), it can be seen that the classification utilized in the present study regarding the type of sewage treatment system was somewhat different. This is due to the fact that the present survey has sought a classification that better reflects the conditions of this service in the study area. It should be noted that the IBGE classification does not apply well to the study area, and it masks the actual sewage collection and treatment status in this locality since it has as one of its classes as "general sewage or rainwater network". This classification presents two basic problems: 1) it does not discriminate if the sewage carried by this network is carried to a treatment station, or if it is released in natura; and 2) the rainwater network can only be considered as part of the sewage system in the few cases, where it is utilized a type of united network system. Notwithstanding, in this study site the rainwater network was not designed to conduct sewage, and in cases where it does (unduly), this sewage is released directly into the local water bodies.

Table 3 shows the group of interviewees who uses oral contraceptives $(n=95)$. In addition to general data, data on the consumption of these pharmaceuticals is also presented.

A proportional distribution between two age groups was observed among the interviewees who use oral contraceptives: $50.5 \%$ were between 15 and 29 years old and $48.4 \%$ were between 30 and 44 years old, leaving only $1.1 \%$ of women aged over 45. According to Tavares (2006), older women are less likely to choose hormonal methods, since they believe they are at lower risks for pregnancy, so usually going for other methods, which can also be seen in this study results.

Table 3 also presents data on the schooling of those interviewed who use oral contraception, where approximately $73 \%$ of them report having at least high school education. It is noted that the educational level of women who use oral contraceptives $(n=95)$ is similar to the pattern observed for the whole sample $(n=325)$.

Regarding the households of the interviewed who use oral contraceptives, $76.8 \%$ of the interviewees stated that their households have a public water supply system and $58.9 \%$ stated that their sewers are released in natura in water bodies draining the region of study. This percentage of non-treatment of sewage is another indicator of the relevance of the study of emerging micropollutants in the waters of these water bodies.

Among the consumed oral contraceptives, 95.8\% have synthetic estrogen EE2 as the main active principle (Table 3). Those which do not present EE2 as the active principle, containing only progestogen and/or the natural estrogen $17 \beta$-estradiol.

Graphic 1 shows the results regarding the pattern of consumption of oral contraceptives most consumed by the women in the studied area. It was observed that, of the most consumed oral contraceptives, almost $50 \%$ have a dosage of $0.03 \mathrm{mg}$ EE2. 
Table 3: General characterization of oral contraceptives users $(n=95)$ and consumption prevalence according to the studied variables.

\begin{tabular}{|c|c|c|}
\hline \multirow{2}{*}{ Variables } & \multicolumn{2}{|c|}{ Sample } \\
\hline & $\mathbf{N}$ & $\%$ \\
\hline \multicolumn{3}{|l|}{ Oral contraceptives formulation } \\
\hline Contains EE2 & 91 & 95.8 \\
\hline Does not contain EE2 & 4 & 4.2 \\
\hline \multicolumn{3}{|c|}{$\begin{array}{l}\text { Oral contraceptives consumption } \\
\text { (years) }\end{array}$} \\
\hline$<1$ & 15 & 15.8 \\
\hline 1 to 3 & 26 & 27.4 \\
\hline 4 to 7 & 27 & 28.4 \\
\hline$>7$ & 27 & 28.4 \\
\hline \multicolumn{3}{|l|}{ Age group (years) } \\
\hline 15 to 29 & 48 & 50.5 \\
\hline 30 to 44 & 46 & 48.4 \\
\hline 45 to 59 & 1 & 1.1 \\
\hline \multicolumn{3}{|l|}{ Scholarity (study years) } \\
\hline$\geq 12$ & 19 & 20.0 \\
\hline 9 to 11 & 46 & 48.4 \\
\hline$\leq 8$ & 30 & 31.6 \\
\hline \multicolumn{3}{|l|}{ Employed } \\
\hline Yes & 83 & 87.4 \\
\hline No & 12 & 12.6 \\
\hline \multicolumn{3}{|c|}{$\begin{array}{l}\text { Location where oral contraceptive was } \\
\text { obtained }\end{array}$} \\
\hline In Santa Maria Madalena & 83 & 87.4 \\
\hline Drugstore & 76 & 80 \\
\hline Health Center & 7 & 7.4 \\
\hline Other municipalities & 12 & 12.6 \\
\hline
\end{tabular}

It should be clarified that, while the oral contraceptives presented here are classified by their EE2 dosage, their commercial names were also acquired. And when analyzing these data, one important feature is the fact that the four most consumed oral contraceptives, responsible for approximately $50 \%$ of the total, are those with more affordable prices. In view of this behavior, it can be concluded that price is of great relevance regarding the choice of the contraceptive.

Regarding where the oral contraceptives were obtained, local drugstores stand out as being responsible for $80 \%$ of the supply of these pharmaceuticals in the studied area. To complement the survey, data on the distribution of oral contraceptives were also collected in the two local health centers (Almeida Santos Colombian Family Health Program and Doutor Manoel Verbicário Central Health Unit) and in the all five drugstores located in the study area, where monthly sales records were accessed, as shown in Graphic 2.

Similar to the results shown in Graphic 1, Graphic 2 indicates that about $50 \%$ of the oral contraceptives supplied by the surveyed health centers and drugstores also contain a $0.03 \mathrm{mg}$ EE2 dosage. However, higher values of dispensation were found in relation to oral contraceptives that do not present EE2 in their formulation.

The available technical and academic literature indicates that still there are not many studies regarding the characterization of pharmaceuticals consumption by the Brazilian population. According to the National Health Council (CNS), medicines more easily purchased at drugstore counters are among the most widely used pharmaceuticals in Brazil and include contraceptives, analgesics, and antiinflammatories (CNS, 2005). Regarding contraceptive methods, studies indicate that oral contraception is the most used method, followed by female sterilization (tubal ligation), condoms, intrauterine devices (IUD) and the diaphragm.

The Ministry of Health PNDS carried out a study that approached 8,707 married women (15-44 years old) and found that, in general, the prevalence of contraception in Brazil is notably high ( $81 \%$ used some contraceptive method) being the most utilized methods the female/male sterilization (31\%) and the oral contraception (27\%), followed by the use of condoms (13\%) and other methods (10\%) (Ministério da Saúde, 2009).

In Pelotas city, located in the state of Rio Grande do Sul, a cross-sectional study was carried out on the use of contraceptive methods on women aged 20 to 49 residing in the urban area. The study concluded that the use of oral contraceptives was the most applied method among women, followed by tubal ligation and condoms (Dias-da-Costa et al., 2002). This profile was also observed in a study conducted with women between 20 and 60, with active sex lives, in the urban area of São Leopoldo, also in the state of Rio Grande do Sul, and in another study carried out in the state of Paraná, on people of the public health aged 35 to 49 enrolled in the Maringá Family Health Program (Carreno et al., 2006; Souza et al., 2006).

At Tubarão, located in the state of Santa Catarina, the contraceptive method most used by undergraduate medical students with ages between 18 and 41 was also oral contraception, followed by combinations of methods (oral contraception plus condoms) and condoms (Neumann et al., 2011). Other studies, such as the one performed by Molina et al. (2015) in Cuiabá, located in the state of Mato Grosso, analyzing contraceptive methods and their uses in adolescents, and also demonstrated that combinations of methods (oral contraceptive plus condoms) were the most frequent.

Studies carried out in southeastern Brazil, in the São Paulo city with on women aged 10 to 49, in Campinas city with on women aged 30 to 49 and in three units of the Unified Health System in the State of Rio de Janeiro with women aged 18 to 39 , also verified a prevalence of oral contraception methods and condoms (Heilborn et al., 2009; Espejo et al., 2003; Schor et al., 2000).

At the global scale, the United Nations Department of Economic and Social Affairs in 2012 compiled data on 
contraceptive methods used in several countries. Portugal and France stand out among the countries with higher rates of oral contraception use, of $60 \%$ and $41.5 \%$, respectively. Comparing Brazil to other countries, with regard to oral contraceptives consumption as a contraception method, it presents similar levels as the United Kingdom, Norway, Australia, and Chile, with values of the order of $30 \%$ (United Nations, 2012).

It should be noted that in the present study no data were sought on all contraceptive methods such as: condom use, tubal ligation, IUD use, emergency pill, among others. The quantitative data here presented focus withal on the use of oral contraceptives, and it is probable that a significant number of the surveyed women who do not use this method use some other method of contraception, such as condoms or sterilization (tubal ligation). On the other hand, although the objective of this study is to analyze the pattern of EE2 consumption (found in formulations of a large part of oral contraceptives), given the scarcity of epidemiological information on this subject, the presented results can serve as a basis for elaboration of new studies.

\section{Estimated Concentrations of EE2 in the Water Bodies and Possible Impacts}

In view of the data presented herein and the pharmacological characteristics of EE2, it is possible to establish an approximate value of the release of this synthetic estrogen into the water bodies that drain the study area.

Based on Table 3, which presents the dosage of the active principle of interest (EE2) in the oral contraceptive formulations consumed by these women, the average daily consumption of $27 \mu \mathrm{g}$ day $^{-1}$ can be calculated for the urban area of the $1^{\text {st }}$ district of Santa Maria Madalena. It should be noted that, in general, the active oral contraceptives that contain EE2 are administered only during 3 of the 4 weeks of the menstrual cycle. Therefore, the average daily consumption of $20 \mu \mathrm{g}$ day $^{-1}$ was considered for the study region.

As presented in the study done by Johnson and Williams (2004), it is important to consider the excretion rate of this estrogen in relation to the total ingested content. This rate is variable according to a series of factors, such as age, race, diet, and other interferences of the human metabolism. Even so, it is possible to utilize average values in order to facilitate studies like the one conducted herein. Thus, $40 \%$ was used as the excretion rate of EE2 in its free form or estrogenically active conjugate, being $23 \%$ in feces and $17 \%$ in urine (Figure 2). Therefore, it was possible to estimate that each woman using oral contraception releases an average load of $8 \mu \mathrm{g}$ day $^{-1}$ of EE2 in sewage, which is then released to the local water bodies.

Employing the 95 women amongst the 325 interviewees as being statistically representative of the urban area of study, it is coherent to extrapolate the release value $\left(8 \mu \mathrm{g} \mathrm{day}^{-1}\right)$ to 602 women $(29.3 \%$ of the total population of women aged $15-59$ residing in the study area, totaling 2,054 women). Thus, it resulted in a total release value of EE2 in the study area of $4.8 \mathrm{mg} \mathrm{day}^{-1}$.

When considering the characteristics of local sanitation (in natura sewer release or treatment technology not efficient in the removal of EE2), it is estimated that the most, even all, of this compound go into the local water bodies. Then assuming that the sum of the flow of the two streams that drain the study area is of a relatively small order $\left(\cong 280 \mathrm{~L} \mathrm{~s}^{-1}\right)$ - which limits their dilution capacity - the relevance of this release into these water bodies is increased. Considering that the estimated EE2 daily release $\left(4.8 \mathrm{mg} \mathrm{day}^{-1}\right)$ is done in a period of about 16 hours (discounting 8 hours of sleep), it was calculated for the area of study an environmental concentration of approximately $0.3 \mathrm{ng} \mathrm{L}^{-1} \mathrm{EE} 2$.

The literature has shown that very low concentrations $(<$ $1 \mathrm{ng} \mathrm{L}^{-1}$ ), close to what was estimated for the water bodies of the study region, may already trigger adverse effects on species. According to Hoffmann and Kloas (2012) male amphibians of the species Xenopus laevis exposed to $0.3 \mathrm{ng}$ $\mathrm{L}^{-1}$ of EE2 had their mating behavior affected and became less attractive for females selection. Dang et al. (2017) showed that acute exposure to EE2 at low concentrations in the order

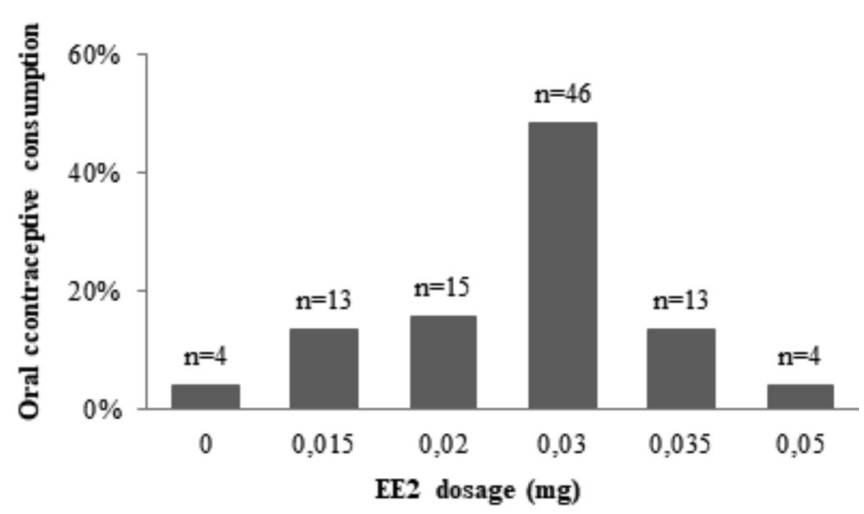

Graphic 1: Consumption pattern of oral contraceptives $(n=95)$ in the study area.

In oral contraceptives with different synthetic estrogen dosages, i.e., bi or threephase formulations, the most prevalent dosage was considered. For example, in biphasic formulas containing seven $0.04 \mathrm{mg}$ EE2 pills and twenty-two $0.03 \mathrm{mg}$ EE2 tablets, it was considered the EE2 dosage of $0.03 \mathrm{mg}$.

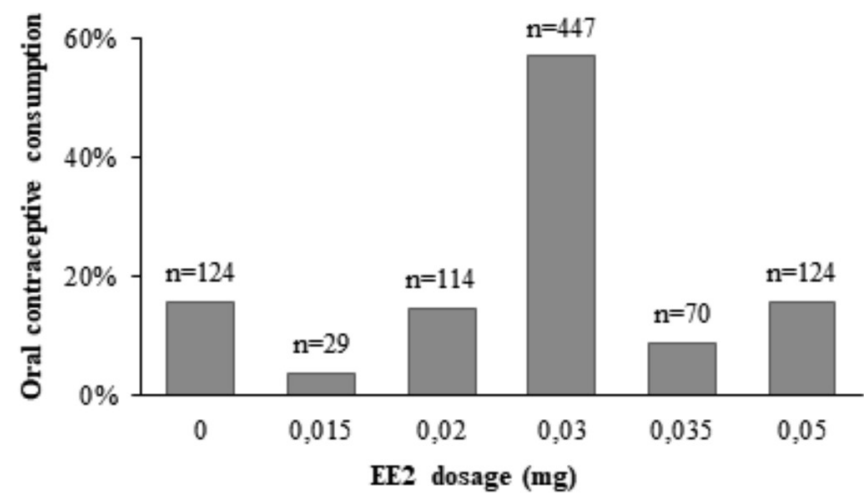

Graphic 2: Monthly distribution of oral contraceptives at health centers and drugstores in the urban area of the $1^{\text {st }}$ district of Santa Maria Madalena.

*In oral contraceptives with different synthetic estrogen dosages, i.e., bi or three-phase formulations, the most prevalent dosage was considered. For example, in biphasic formulas containing seven $0.04 \mathrm{mg}$ EE2 pills and twenty-two $0.03 \mathrm{mg}$ EE2 pills, it was considered theEE2 dosage of $0.03 \mathrm{mg}$. 


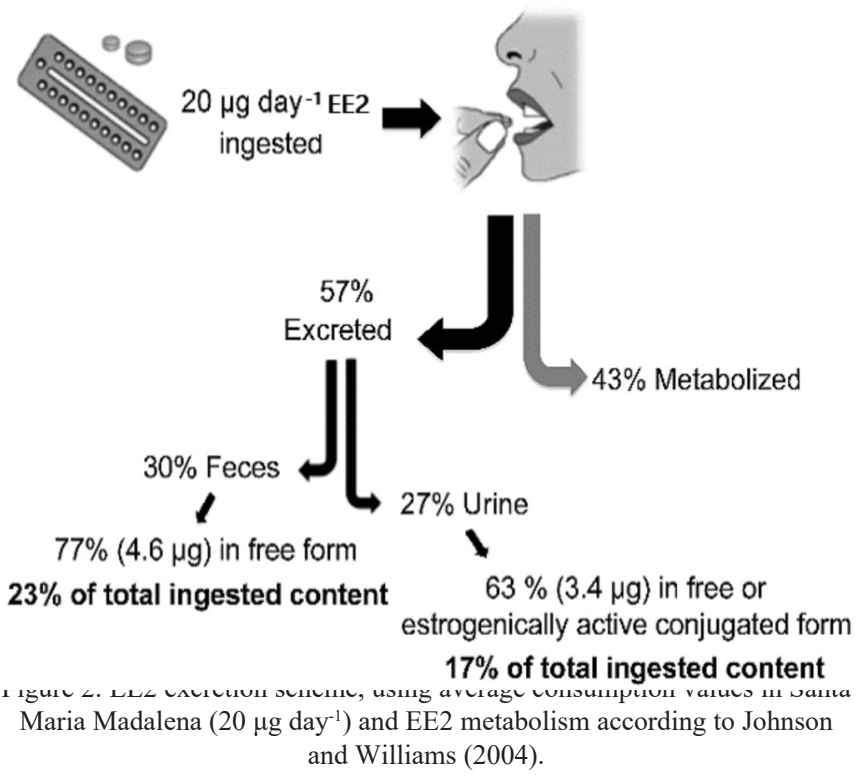

of 0.5 to $5 \mathrm{ng} \mathrm{L}^{-1}$ altered the behavior of the male mosquito (Gambusia affinis), becoming it more aggressive. Studies to assess changes in the immune system catfish (Sparus aurata $L$.) indicate that after 15 days of exposure to EE2 at concentrations between 0.5 and $5 \mathrm{ng} \mathrm{L}^{-1}$ can change the fish's ability to adequately respond to infection (Cabas et al . 2012). An assessment of the potential endocrine responses promoted by EE2 in different species led the European Commission to propose in 2012 a limit of this estrogen in surface waters. This study considered the adverse effects on fish associated with different concentrations of EE2. It was concluded that the no observed adverse effect level (NOAEL) is $0.035 \mathrm{ng} \mathrm{L}^{-1}$ of EE2; between 0.1 and $0.2 \mathrm{ng} \mathrm{L}^{-1}$ it is already possible to observe some adverse effects (LOAEL); at the concentration of $1 \mathrm{ng} \mathrm{L}^{-1}$ it is possible to induce the vitellogenin in male fish and at $4 \mathrm{ng} \mathrm{L}^{-1}$ the feminization of these; and values above 5 ng $\mathrm{L}^{-1}$ can impose population damages (Cunha et al., 2016; Gilbert, 2012).

It should be noted that EE2 is not the only compound released into water bodies that can induce potential endocrine disruption. Moreover, as documented in the literature, EE2 associated with other compounds may trigger even more severe adverse effects, due to additive and synergistic mechanisms (Fent et al., 2006). According to Hua et al. 2016, the combined exposure of megestrol acetate (progestogen) and EE2 in zebra fish (Danio rerio) caused a further reduction in fertility compared to exposure to EE2 alone, suggesting an additive effect on egg production when EE2 is supplemented with this progestogen. Örn et al. (2016) observed that exposure to mixtures of EE2 with 17ß-trenbolone (androgen) affects the process of gonad differentiation in zebra fish and leads to sexual interruption.

\section{CONCLUSIONS}

In view of the discussion conducted by the present study, it is pertinent to highlight the relevance of the synthetic estrogen EE2 as an important micropollutant and endocrine disruptor, and which can cause significant potential adverse effects in the aquatic biota.

The area selected for the elaboration of this study, the $1^{\text {st }}$ district of Santa Maria Madalena, in Rio de Janeiro, presented itself as a favorable region for the development of this study since it was possible to access STPs, health units, drugstores, and other relevant points of information.

Regarding the survey, the contact with the interviewees can be evaluated as positive, since it introduced a topic of interest for public health and the environment, which brings forward discussions on environmental sanitation.

Based on the information obtained through a surveytype study that addressed a representative sample of women residing in the study area, a similar pattern of oral contraceptive consumption was found compared to that observed in studies with a national scope, in which about $30 \%$ of the interviewees use such pharmaceuticals.

In addition, it was also observed that most of the sanitary effluents produced in this municipality go untreated before being released into the local water bodies. This is because a considerable part of the households is not connected to the sewage network, or because several localities have this network, but it is not linked to any treatment stations. This reality, unfortunately, can be observed throughout the entire country, which constitutes an important challenge for public and environmental health.

From the information obtained it was possible to estimate the occurrence of a considerable release of EE2 into the water bodies of Santa Maria Madalena, which suggests the possible threat to the local aquatic biota.

Due to the risks related to the introduction of these pharmaceuticals in the aquatic environment, studies on the improvement of wastewater treatment technologies have increasingly advanced with the aim of achieving greater efficiency in the removal of estrogens and other contaminants. In addition, some countries in the European Union and the United States have increasingly aimed to extend the regulations and monitoring of new compounds, not previously addressed by legal provisions regarding the control of water pollutants, such as EE2 (Cunha et al., 2016).

\section{REFERENCES}

BHANDARI, R. K., VOM SAAL, F. S., TILLITT, D. E. 2015. Transgenerational effects from early developmental exposures to bisphenol A or $17 \alpha$-ethinylestradiol in medaka, Oryzias latipes. Sci Rep, 5(9303), 1-6. https://doi.org/10.1038/srep09303

CABAS, I., LIARTE, S., GARCÍA-ALCÁZAR, A., MESEGUER, J., MULERO,V.,GARCÍA-AYALA,A. 2012.17 $\alpha$-Ethynylestradiol alters the immune response of the teleost gilthead seabream (Sparus aurata L.) both in vivo and in vitro. Dev Comp Immunol, 36(3), 547-556. http://dx.doi.org/10.1016/j.dci.2011.09.011

CARRENO, I., DIAS-DA-COSTA, J. S., OLINTO, M. T. A., MENEGHEL, S. 2006. Uso de métodos contraceptivos entre mulheres com vida sexual ativa em São Leopoldo, Rio Grande do Sul, Brasil. Cad Saude Publica, 22, 1101-1109. http://dx.doi. 
org/10.1590/S0102-311X200600050002

CNS (Conselho Nacional de Saúde). 2005. Consumo de medicamentos: um autocuidado perigoso. Retrieved February 02, 2016, from http://www.conselho.saude.gov.br/ultimas noticias/2005/medicamentos.htm

CNS (Conselho Nacional de Saúde. Resolução). 1996. CNS nº 196, de 10 de outubro de 1996. Aprova diretrizes e normas regulamentadoras de pesquisas envolvendo seres humanos.

DANG, H. M., INAGAKI, Y., YAMAUCHI, Y., KURIHARA, T., VO, C. H., SAKAKIBARA, Y. 2017. Acute exposure to $17 \alpha$-ethinylestradiol alters aggressive behavior of mosquitofish (Gambusia affinis) toward japanese medaka (Oryzias latipes). Bull Environ Contam Toxicol, 98(5), 643-648. http://dx.doi. org/10.1007/s00128-016-2016-Z

CUNHA, D. L., SILVA, S. M. C., BILA, D. M., OLIVEIRA, J. L. M., SARCINELLI, P. N., LARENTIS, A. L. 2016. Regulamentação do estrogênio sintético $17 \alpha$-etinilestradiol em matrizes aquáticas na Europa, Estados Unidos e Brasil. Cad Saude Publica, 32, 1-13. http://dx.doi.org/10.1590/0102-311X00056715

DIAS-DA-COSTA, J. S., GIGANTE, D. P., MENEZES, A. M. B., OLINTO, M. T. A., MACEDO, S., BRITTO, M. A. P., FUCHS, S. C. 2002. Uso de métodos anticoncepcionais e adequação de contraceptivos hormonais orais na cidade de Pelotas, Rio Grande do Sul, Brasil: 1992 e 1999. Cad Saude Publica, 18, 93-99. http:// dx.doi.org/10.1590/S0102-311X2002000100010

ESPEJO, X., TSUNECHIRO, M. A., OSIS, M. J. D., DUARTE G. A., BAHAMONDESE, L., SOUSA, M. H. 2003. Adequação do conhecimento sobre métodos anticoncepcionais entre mulheres de Campinas, São Paulo. Rev Saude Publica, 37, 583-590. http:// dx.doi.org/10.1590/S0034-89102003000500006

FENT, K., WESTON, A. A., CAMINADA, D. 2006. Ecotoxicology of human pharmaceuticals. Aquat Toxicol, 76, 122-159. https:// doi.org/10.1016/j.aquatox.2005.09.009

GARMSHAUSEN, J., KLOAS, W., HOFFMANN, F. 2015. $17 \alpha$-ethinylestradiol can disrupt hemoglobin catabolism in amphibians. Comp Biochem Physiol C Toxicol Pharmacol, 171, 4-40. https://doi.org/10.1016/j.cbpc.2015.03.004

GILBERT, N. 2012. Drug-pollution law all washed up. Nature, 491, 503-504. 10.1038/491503a

GIUSTI, A., LAGADIC, L., BARSI, A., THOMÉ, J., JOAQUIMJUSTO, C., DUCROT, V. 2014. Investigating apical adverse effects of four endocrine active substances in the freshwater gastropod Lymnaea stagnalis. Sci Total Environ, 493, 147-155. https://doi.org/10.1016/j.scitotenv.2014.05.130

HEBERER, T. 2002. Occurrence, fate, and removal of pharmaceutical residues in the aquatic environment: a review of recent research data. Toxicol Lett, 131, 5-17. https://doi.org/10.1016/S03784274(02)00041-3

HEILBORN, M. L., PORTELlA, A. P., BRANDÃO, E. R., CABRAL, C. S., GRUPO CONPRUSUS. 2009. Assistência em contracepção e planejamento reprodutivo na perspectiva de usuárias de três unidades do Sistema Único de Saúde no Estado do Rio de Janeiro, Brasil. Cad Saude Publica, 25, 269-278. https://doi.org/10.1590/S0102-311X2009001400009

HOFFMANN, F., KLOAS, W. 2012. Estrogens can disrupt amphibian mating behavior. PLoS One, 7, e32097. https://doi. org/10.1371/journal.pone.0032097

HUGO, T. D., MAIER, V. T., JANSEN, K., RODRIGUES, C. E. G., CRUZEIRO, A. L. S., ORES, L. C., PINHEIRO, R. T., SILVA, R., SOUZA, L. D. M. 2011. Factors associated with age at first intercourse: a population-based study. Cad Saude Publica, 27, 2207-2214. http://dx.doi.org/10.1590/S0102$311 \mathrm{X} 2011001100014$

HUA, J., HAN, J., WANG, X., GUO, Y., ZHOU, B. 2016. The binary mixtures of megestrol acetate and $17 \boldsymbol{\alpha}$-ethynylestradiol adversely affect zebrafish reproduction. Environ Pollut, 213, 776-784. https://doi.org/10.1016/j.envpol.2016.03.031

IBGE (Instituto Brasileiro de Geografia e Estatística). 2010. Censo Demográfico. Retrieved

September 27, 2015, from http:/www.ibge.gov.br/home/presidencia/ noticias/guia_do_censo_2010_operacao.php

JASER, W., SEVERIN, G. F., JÜTTING, U., JÜTTNER, I., SCHRAMM, K. W., KETTRUP, A. 2003. Effects of 17alphaethinylestradiol on the reproduction of the cladoceran species Ceriodaphnia reticulata and Sida crystallina. Environ Int, 28, 633-638. https://doi.org/10.1016/S0160-4120(02)00101-0

JIN, S., YANG, F., XU, Y., DAI, H., LIU, W. 2013. Risk assessment of xenoestrogens in a typical domestic sewage-holding lake in China. Chemosphere, 93, 892-898. https://doi.org/10.1016/j. chemosphere.2013.05.037

JOHNSON, A. C., WILLIAMS, R. J. 2004. A model to estimate influent and effluent concentrations of estradiol, estrone, and ethinylestradiol at sewage treatment works. Environ Sci Technol, 38, 3649-3658. 10.1021/es035342u

LUNA, T. O., PLAUTZ, S. C., SALICE, C. J. 2015. Chronic effects of $17 \alpha$-ethinylestradiol, fluoxetine, and the mixture on individual and population-level end points in Daphnia magna. Arch Environ Contam Toxicol, 68, 603-611. https://doi.org/10.1007/ s00244-014-0119-2

METCALFE, C. D., METCALFE, T. L., KIPARISSIS, Y., KOENIG, B. G., KHAN, C., HUGHES, R. J., CROLEY, T. R., MARCH, R. E., POTTER, T. 2001. Estrogenic potency of chemicals detected in sewage treatment plant effluents as determined by in vivo assays with Japanese medaka (Oryzias latipes). Environ Toxicol Chem, 20, 297-308. https://doi.org/10.1002/etc.5620200210

MINISTÉRIO DA SAÚDE. Pesquisa Nacional de Demografia e Saúde da Criança e da Mulher (PNDS). Dimensões do processo reprodutivo e da saúde da criança. Capítulo 5: Desigualdade socioeconômica na utilização de métodos anticoncepcionais no Brasil: uma análise comparativa com base nas PNDS 1996 e 2006. Brasília: DF. 2009.

MOLINA, M. C. C., STOPPIGLIA, P. G. S., MARTINS, C. B. G., ALENCASTRO, L. C. S. 2015. Conhecimento de adolescentes do ensino médio quanto aos métodos contraceptivos. Mundo da Saúde.

NEUMANN, A. F., ROSA-NETO, F., RIO, C. L., SAKAE, T. M. 2011. Perfil da sexualidade feminina em universitárias de um curso de medicina de Santa Catarina. Arq Catarin de Med, 40(1), 57-65.

ÖRN, S., HOLBECH, H., NORRGREN, L. 2016. Sexual disrupting in zebrafish (Danio rerio) exposed to mixtures of $17 \alpha$ ethinylestradiol and 17ß-trenbolone. Environ Toxicol Phar, 41, 225-231. https://doi.org/10.1016/j.etap.2015.12.010

PEDRO, A. O., PINTO NETO, A. M., PAIVA, L. H., OSIS, M. J., HARDY, E. 2003. Age at natural menopause among Brazilian women: results from a population-based survey. Cad Saude Publica, 19, 7-25. http://dx.doi.org/10.1590/S0102311X2003000100003

PMSB (Plano Municipal de Saneamento Básico de Santa Maria Madalena). 2012. Plano regional de saneamento com base municipalizada nas modalidades água, esgoto e drenagem urbana. DRZ Gestão Ambiental.

RUNNALLS, T. J., MARGIOTTA-CASALUCI, L., KUGATHAS, S., SUMPTER, J. P. 2010. Pharmaceuticals in the aquatic environment: steroids and anti-steroids as high priorities for research. Hum Ecol Risk Assess, 16(6), 1318-1338. https://doi. org/10.1080/10807039.2010.526503

SALIERNO, J. D., KANE, A. S. 2009. 17alpha-ethinylestradiol 
alters reproductive behaviors, circulating hormones, and sexual morphology in male fathead minnows (Pimephales promelas). Environ Toxicol Chem, 28, 953-961. http://dx.doi. org/10.1897/08-111

SCHOR, N., FERREIRA, A. F., MACHADO, V. L., FRANÇA, A. P., PIROTTA, K.C. M., ALVARENGA, A. T., SIQUEIRA, A. A. F. 2000. Mulher e anticoncepção: conhecimento e uso de métodos anticoncepcionais. Cad Saude Publica, 16, 377-384. http://dx.doi.org/10.1590/S0102-311X2000000200008

SOUZA, J. M. M., PELLOSO, S. M., UCHIMURA, N. S, SOUZA, F. 2006. Utilização de métodos contraceptivos entre as usuárias da rede pública de saúde do município de Maringá-PR. Rev Bras Ginecol Obstet, 28, 271-277. http://dx.doi.org/10.1590/S010072032006000500002

SUMPTER, J. P., JOHNSON, A. C. 2005. Lessons from endocrine disruption and their application to other issues concerning trace organics in the aquatic environment. Environ Sci Technol, 39(12), 4321-4332. https://doi.org/10.1021/es048504a

TAVARES, L. S., LEITE, I. C., TELLES, F. S. P. 2007. Necessidade insatisfeita por métodos anticoncepcionais no Brasil. Rev Bras Epidemiol, 10(2), 139-148. http://dx.doi.org/10.1590/S1415-
790X2007000200002

UNITED NATIONS, Department of Economic and Social Affairs, Population Division. World Contraceptive Use 2012. Retrieved December 10, 2015, from http://www.un.org/esa/population/ publications/WCU2012/MainFrame.html

VAN AERLE, R., POUNDS, N., HUTCHINSON, T. H., MADDIX, S., TYLER, C. R. 2002. Window of sensitivity for the estrogenic effects of ethinylestradiol in early life-stages of fathead minnow, Pimephales promelas. Ecotoxicology, 11, 423-434. 10.1023/A:1021053217513

VOLKOVA, K., REYHANIAN, N. C., PORSERYD, T., HALLGRENA, S., DINNÉTZA, P., PORSCH-HÄLLSTRÖMA, I. 2015. Developmental exposure of zebrafish (Danio rerio) to 17-ethinylestradiol affects non-reproductive behavior and fertility as adults, and increases anxiety in unexposed progeny. Horm Behav, 73, 30-38. https://doi.org/10.1016/j.yhbeh.2015.05.014

ZHA, J., WANG, Z., WANG, N., INGERSOLL, C. 2007. Histological alternation and vitellogenin induction in adult rare minnow (Gobiocypris rarus) after exposure to ethynylestradiol and nonylphenol. Chemosphere, 66, 488-495. https://doi. org/10.1016/j.chemosphere.2006.05.071 